\title{
Comparison of methods for particulate phase mercury analysis: sampling and analysis
}

Received: 28 March 2002 / Revised: 8 August 2002 / Accepted: 27 August 2002 / Published online: 24 October 2002

(C) Springer-Verlag 2002

\begin{abstract}
Accurate and reliable sampling and analysis of mercury forms is an overriding aim of any atmospheric monitoring effort which seeks to understand the fate and transport of the metal in the environment. Although a fraction of the total mercury forms found in the atmosphere, particulate phase mercury, $\mathrm{Hg}_{\mathrm{p}}$, is believed to play a prominent role in both wet and dry deposition to the terrestrial and aquatic environments. Currently, microwave acid extraction and thermoreductive methodologies for analysis of $\mathrm{Hg}_{\mathrm{p}}$ samples are widely used. We report on the potential for the use of a thermoreductive method for $\mathrm{Hg}_{\mathrm{p}}$ analysis to evaluate and optimize it for use in routine monitoring networks. Pre-baked quartz filters can be placed in particulate samplers with well-characterized size cuts, such as dichotomous samplers and microoriface impactors. The thermoreductive methodology facilitates rapid analysis after sample collection. It requires no chemical extraction thereby eliminating the potential for contamination and generation of hazardous waste. Our results indicate that, on average, the thermoreductive method yields $30 \%$ lower values for fine fraction $\mathrm{Hg}_{\mathrm{p}}$ when compared with microwave acid digestion. This may be due to matrix interferents that reduce the collection efficiency of mercury onto gold preconcentration traps. Results for total particulate mercury samples indicate that on average the thermoreductive method yields $56 \%$ lower values for the coarse fraction when compared with microwave acid digestion.

Experiments were also conducted in Detroit, MI, USA to investigate whether elevated reactive gaseous mercury $\left(\mathrm{Hg}^{2+} \mathrm{g}\right)$ in an urban environment can lead to an artifact during the collection of filters for $\mathrm{Hg}_{\mathrm{p}}$ analysis. Our results indicate a significantly higher amount of $\mathrm{Hg}_{\mathrm{p}}$ collected onto a filter using the conventional methodology as compared to a filter collected downstream of $\mathrm{KCl}$-coated
\end{abstract}

M.M. Lynam · G.J. Keeler (®)

University of Michigan Air Quality Laboratory,

Ann Arbor, MI 48109, USA

e-mail: jkeeler@umich.edu annular denuders in the absence of $\mathrm{Hg}^{2+} \mathrm{g}$. These results point to the presence of $\mathrm{Hg}^{2+}{ }_{\mathrm{g}}$ as an artifact during $\mathrm{Hg}_{\mathrm{p}}$ measurement. These results indicate that a denuder must be utilized upstream of a filter for $\mathrm{Hg}_{\mathrm{p}}$ collection to prevent significant $\mathrm{Hg}^{2+}{ }_{\mathrm{g}}$ artifact formation.

Key words Particulate mercury - Acid digestion . Thermoreduction $\cdot$ Denuder $\cdot$ Sampling artifact

\section{Introduction}

The impact of mercury on human health as well as ecosystems is well documented [1]. Advice on the consumption of fish has been issued by 39 of the 50 states in the US [2]. In its Mercury Report to Congress, the United States Environmental Protection Agency, USEPA, has cited a possible link between anthropogenic releases of mercury to the atmosphere and its presence in fish [2]. In order to better quantitate this link, the agency has cited a specific need for information regarding atmospheric levels of mercury proximate to anthropogenic sources. This requires reliable methods for measuring concentrations of mercury in gaseous and particle phases for use in monitoring networks. Monitoring of particulate phase mercury, $\mathrm{Hg}_{\mathrm{p}}$, has been carried out both in rural [3] and urban locations [4, 5, 6]. Studies in urban locations have shown significant deposition of $\mathrm{Hg}_{\mathrm{p}}$ to adjacent water bodies $[6,7]$.

Aerosol or particulate-phase mercury $\left(\mathrm{Hg}_{\mathrm{p}}\right)$ is a complex atmospheric constituent, likely comprising stable condensed phases as well as adsorbed or dissolved gases and semi-volatile materials. The residence time of $\mathrm{Hg}_{\mathrm{p}}$ in the atmosphere is primarily a function of its particle size and ranges from hours to many days [8]. It is typically collected by pulling air through a glass fiber or quartz filter with that portion trapped on the filter operationally defined as $\mathrm{Hg}_{\mathrm{p}}$. However, uncertainties with this method of sampling exist; relatively long sampling times are typically required and the filter material may come in contact with large volumes of air containing gaseous forms of mercury resulting in a gain of these species by the filter 
surface $[9,10]$. Conversely, during long sampling times, as air is being continuously pulled through the filter, evaporation of water or desorption of weakly bound species may lead to losses of mercury from the filter. Furthermore, other chemical species captured on the filter may promote heterogeneous reactions during sampling.

The recognition that gas-phase species affect aerosols on filters during collection has spawned the use of denuders. Diffusion denuders have long been used to separate gas-phase species (e.g. nitric acid, ammonia) that interfere with filter measurements during atmospheric sampling of airborne pollutants $[11,12]$. Their inner surface is coated with a reactive substance that capture the gas(es) of interest. Denuders have been coupled to various inlets, such as Teflon-coated cyclones, for removal of particles larger than $2.5 \mu \mathrm{m}$ from the air stream before entering the denuder allowing the smaller particles to pass through without depositing under laminar flow conditions [13].

Reactive gaseous mercury, $\mathrm{Hg}^{2+}{ }_{\mathrm{g}}$, is known to be emitted from major sources like coal-fired power plants and municipal incinerators. The USEPA showed that greater than $90 \%$ of the mercury emissions from municipal and medical waste incinerators were in the oxidized form [14]. Results from modeling of incinerator flue gases suggest that mercuric chloride, $\mathrm{HgCl}_{2}$, is a dominant species of mercury present [15]. Landis et al. [16] have shown that annular denuders coated with potassium chloride collect mercuric chloride efficiently ( $>96 \%)$ at a flow rate of $10 \mathrm{~L} \mathrm{~min}^{-1}$ for samples $\leq 5 \mathrm{~h}$. The mean precision for collocated pairs of denuders was found to be $15 \%$.

To date, one study has assessed the potential importance of $\mathrm{Hg}^{2+}$ g sampling artifacts associated with ambient $\mathrm{Hg}_{\mathrm{p}}$ measurements. The USEPA conducted a study of speciated mercury emissions from a large anthropogenic point source in 2000 (Kinsey JS et al., submitted for publication). As part of the study, Landis et al [16], characterized an $\mathrm{Hg}^{2+}{ }_{\mathrm{g}}$ artifact on filters for $\mathrm{Hg}_{\mathrm{p}}$ analysis at a source impacted site. This data revealed a significant artifact due to $\mathrm{Hg}^{2+}{ }_{\mathrm{g}}$ associated with the measurement of $\mathrm{Hg}_{\mathrm{p}}$.

Much of the previous work has centered on development of analytical methods for the detection of $\mathrm{Hg}_{\mathrm{p}}$. The use of $\mathrm{KCl}$-coated annular denuders may help to eliminate one bias in the determination of $\mathrm{Hg}_{\mathrm{p}}$, namely, gains of $\mathrm{Hg}^{2+}{ }_{\mathrm{g}}$ by the filter as a result of the passage of large volumes of air through the filter during long sampling times.

This paper describes our efforts at optimizing a thermal method of analysis for $\mathrm{Hg}_{\mathrm{p}}$ and presents results of experiments aimed at quantifying potential positive artifacts due to $\mathrm{Hg}^{2+}{ }_{\mathrm{g}}$ during $\mathrm{Hg}_{\mathrm{p}}$ measurement. The ability to quantify this artifact is critical in the assessment of atmospheric mercury deposition to the biosphere and will help quantify $\mathrm{Hg}_{\mathrm{p}}$ measurement uncertainties which limit our present understanding of this process.

\section{Experimental}

Field sampling for $\mathrm{Hg}_{\mathrm{p}}$ was carried out in 1999 (Ann Arbor, MI, USA) and in 2000 (Detroit, MI, USA). The Ann Arbor site is best characterized as suburban and is surrounded by residential/com- mercial property. There are no major industrial sources in the vicinity of this site. The Detroit site is located in an urban area, the Rouge Industrial complex located west north west of the site comprises automobile manufacturing and steel production. In addition, the site is strongly influenced by local traffic as the Ambassador bridge located east north east of the site is the largest border crossing between the United States and Canada. The sampling in Ann Arbor was conducted on the roof of a building at the University of Michigan $-9 \mathrm{~m}$ above ground. The sampling in southwest Detroit was carried out on the roof of a mobile laboratory $6 \mathrm{~m}$ above ground, proximate to the Ambassador Bridge. Ultra-clean sampling and analysis techniques were used; sampling equipment comprising Teflon filter packs, forceps and petri dishes were acidcleaned prior to use in the field [5].

Filters were either baked at $500^{\circ} \mathrm{C}$ for $1 \mathrm{~h}$ (glass fiber) or baked under nitrogen for $1 \mathrm{~h}$ at $500^{\circ} \mathrm{C}$ (quartz) prior to sampling to reduce the background mercury levels. Particle-free gloves were used during the sampling procedures.

Total suspended particulate mercury (TPM) samples were collected using open-faced filter packs onto $47 \mathrm{~mm}$ quartz filters (Whatman) for $24 \mathrm{~h}$ at a flow rate of $30 \mathrm{~L} \mathrm{~min}^{-1}$. Fine particulate $(<2.5 \mu \mathrm{m})$ mercury samples were collected onto filters using Teflon coated cyclones (URG Corporation, Chapel Hill, NC, USA) at a flow rate of $16.7 \mathrm{~L} \mathrm{~min}^{-1}$. After sampling the filters were placed in acid-cleaned petri dishes which were then sealed with Teflon tape. Samples were stored at $-40^{\circ} \mathrm{C}$ until analysis. Flow rates were checked with calibrated rotameters on a daily basis.

Samples were analyzed using either microwave-assisted acid digestion [5] or pyrolysis [10]. Acid digestion involved the extraction of each filter with $20 \mathrm{~mL}$ of a $10 \%\left(\mathrm{v} / \mathrm{v}, 1.6 \mathrm{~mol} \mathrm{~L}^{-1}\right)$ dilution of concentrated nitric acid followed by digestion of the filter in a Teflon vessel for $20 \mathrm{~min}$ at $160^{\circ} \mathrm{C}$ (70 psi) using a CEM MDS-200 computer-controlled microwave unit. The extracts were allowed to cool and were then oxidized with $\mathrm{BrCl}$ and left overnight. The mercury forms in solution were subsequently reduced with $\mathrm{SnCl}_{2}$ and purged out of solution and collected onto a gold trap which was then analyzed by use of a Tekran 2537A cold vapor atomic fluorescence spectroscopy analyzer. This technique when combined with analysis by cold-vapor atomic fluorescence spectrometry (CVAFS) has been shown to be comparable to neutron activation for the NIST Standard Reference Material No. 1648 (1.02 \pm 0.05 vs. $1.07 \pm 0.1)$ and to within $15 \%$ for mercury in foliage samples [17].

Pyrolysis was carried out at $800-900^{\circ} \mathrm{C}$ under nitrogen in a quartz pyrolyzer designed and built at the University of Michigan (Fig. 1), which was directly coupled to a Tekran 2537 analyzer. The pyrolyzer consisted of a quartz tube approximately $50 \mathrm{~cm}$ in length and $0.95 \mathrm{~cm}$ in diameter and contained densely-packed crushed quartz chips in a downstream section for secondary pyrolysis. The pyrolyzer was placed in a tube furnace (Lindberg/Blue $\mathrm{M}$, model TF55035) and connected to a prepurified nitrogen source at its inlet and to the 2537A analyzer at its outlet by means of a 30-cm length of Teflon tubing. A coaxial fan was used at the outlet of the pyrolyzer to prevent heat damage to the Teflon tubing. The furnace was switched on and took approximately $10 \mathrm{~min}$ to reach the desired temperature $\left(800-900^{\circ} \mathrm{C}\right)$. Prior to analysis of the sample filter, the mercury levels in the pyrolyzer were monitored to ensure that low blank levels (less than $1 \mathrm{pg}$ ) were obtained

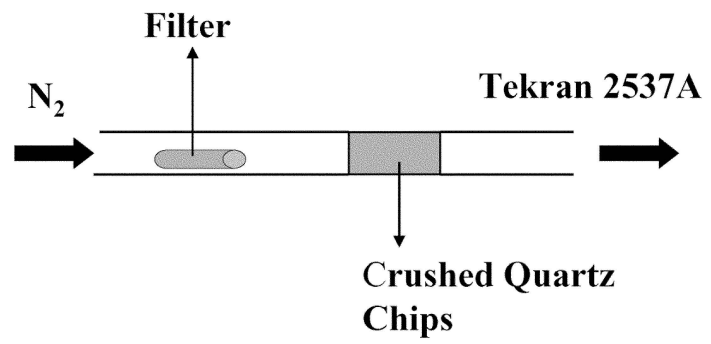

Fig. 1 Pyrolysis unit for thermal analysis of particulate mercury 
before introduction of the sample filter. The sample filter was introduced and heated for approximately $15 \mathrm{~min}$ to drive off all the mercury. Upon completion of the analysis the analyzed filter was removed and the process repeated.

Field and storage blanks were routinely collected with the samples. Field blanks were collected by loading acid-cleaned filter packs with a glass fiber or quartz filter and placing the filter packs in the sampling box for 2 min without drawing air through the system.

Quartz annular denuders were coated with a $\mathrm{KCl}$ solution, dried, and conditioned prior to use following the procedure described by Landis et al. [16]. Bored \#30 end caps containing Teflon-coated ring seals and glass inserts were placed at each end of the denuder tube. The glass inserts were used to couple each end of the denuder to Teflon tubing $(0.64 \mathrm{~cm}$ o.d.). The conditioning procedure involved placing the denuders in a tube furnace (Lindberg/Blue M, model TF55035) and heating them in mercury-free air $\left(1.5 \mathrm{~L} \mathrm{~min}^{-1}\right)$ at $525^{\circ} \mathrm{C}$ for $1 \mathrm{~h}$.

During sampling the denuder was coupled to a Teflon-coated cyclone inlet which removed particles greater than $2.5 \mu \mathrm{m}$ at a flow rate of $10 \mathrm{~L} \mathrm{~min}^{-1}$. The denuder was maintained at $50^{\circ} \mathrm{C}$ with heating tape to prevent hydration of the $\mathrm{KCl}$ coating and to prevent $\mathrm{Hg}^{2+}{ }_{\mathrm{g}}$ loss in the sampling train [16]. The undenuded filter pack was coupled to an identical Teflon-coated cyclone and air was drawn through the filter at a flow rate of $10 \mathrm{~L} \mathrm{~min}^{-1}$. Collocated samples were collected for periods of 10,14 or $24 \mathrm{~h}$. Upon completion of sampling, the denuder and filter packs were removed from the sampling box. Analysis of filters was performed using the EPA-IO5 acid digestion method [18].

Reactive gaseous mercury, $\mathrm{Hg}^{2+}{ }_{\mathrm{g}}$, was also measured in Detroit during July and September 2000 using an automated Tekran 1130 Mercury Speciation unit coupled to a Tekran 2537A Mercury Analyzer. The speciation unit comprises a heated denuder module, a heated sampling line and a controller module. Ambient air was pumped at $10 \mathrm{~L} \mathrm{~min}^{-1}$ through a Teflon-coated heated elutriator inlet in the denuder module. The denuder module contains a potassium chloride-coated annular denuder which removes the $\mathrm{Hg}^{2+}{ }_{\mathrm{g}}$ fraction from the airstream. Upon exiting the denuder the air is filtered using a quartz filter and elemental mercury in the airstream is sampled onto a gold trap in the mercury 2537A analyzer and detected by means of CVAFS. After 12 five-minute sampling intervals have been completed the pump is turned off and zero air is flushed at $6 \mathrm{~L} \mathrm{~min}^{-1}$ through the denuder and sample lines in preparation for desorption of $\mathrm{Hg}^{2+}{ }_{\mathrm{g}}$ from the denuder. After three five-minute flushes the denuder is heated to $500^{\circ} \mathrm{C}$ for $15 \mathrm{~min}$ to release $\mathrm{Hg}^{2+}{ }_{\mathrm{g}}$. Approximately $95 \%$ is liberated during the first $5 \mathrm{~min}$ of heating with the remainder being released in subsequent heating. The reactive gaseous mercury is detected as elemental mercury using CVAFS.

\section{Results and discussion}

\section{Acid digestion versus pyrolysis}

\section{Total and fine particulate mercury in Ann Arbor}

Total and fine particulate filters collected in Ann Arbor, MI during the summer 1999, were analyzed by acid digestion $(\mathrm{AD})$ and the thermal method (TM) described above. Total particulate mercury samples (TPM) showed a greater difference $\left(\mathrm{Hg}_{\mathrm{TM}}=0.44 \times \mathrm{Hg}_{\mathrm{AD}}-0.26, \mathrm{r}^{2}=0.78, \mathrm{~N}=12\right)$ between the two analytical methods in comparison to the fine particulate mercury samples (FPM) $\left(\mathrm{Hg}_{\mathrm{TM}}=1.23 \times \mathrm{Hg}_{\mathrm{AD}}-1.71\right.$, $\mathrm{r}^{2}=0.31, \mathrm{~N}=15$ ). Table 1 summarizes the results of the Ann Arbor experiment. The more pronounced difference between the methods for the TPM samples may reflect the higher crustal component in these samples and indicated
Table 1 Summary of particulate mercury concentrations for total (TPM) and fine fraction (FPM) samples in collected in Ann Arbor, MI during 1999

\begin{tabular}{llcccc}
\hline Type & Analytical method & $\mathrm{N}$ & Median & Min & Max \\
\hline \multirow{2}{*}{ TPM } & Sept 12-Oct 6 & & & & \\
& Acid & 12 & 16 & 5 & 22 \\
& Thermal & 12 & 6 & 1 & 10 \\
& June 27-Aug. 8 & & & & \\
FPM & Acid & 15 & 9 & 3 & 18 \\
& Thermal & 15 & 8 & 2 & 40 \\
\hline
\end{tabular}

to us that the pyrolysis temperature $\left(800^{\circ} \mathrm{C}\right)$ was not sufficiently high.

Biester et al [19] studied mercury in soils and sediments, and found that mercury concentrations determined by pyrolysis gave lower values than those obtained by using aqua regia digestion and cold-vapor atomic absorption spectrometry. In their study, soil samples containing specific mercury compounds such as metallic mercury or cinnabar showed higher RSDs by both pyrolysis and acid digestion in comparison with mercury bound humic acids in soil. The distribution of specific mercury compounds was found to be more heterogeneous in soil samples in comparison to matrix-bound mercury.

Fine particulate samples are mainly anthropogenic in origin [20], the result of combustion processes and are likely to be more homogeneous than the TPM samples.

\section{Fine particulate mercury in Detroit}

Sampling of fine fraction $\mathrm{Hg}_{\mathrm{p}}$ was carried out in Detroit, MI during September 2000. Previous results from Ann Arbor indicated that fine particulate mercury samples showed the best agreement between the two methods. Samples taken in Detroit were pyrolyzed using the TM described above except that a higher temperature of $900{ }^{\circ} \mathrm{C}$ was used. The results shown in Fig. 2 indicate that the thermal method yields values that are approximately $30 \%$ lower. The $\mathrm{r}^{2}=0.90(\mathrm{~N}=13)$ for the relationship between the two sets of data is quite good. The reasons for the apparent discrepancy between the two methods are likely to stem from problems encountered during pyrolysis. Crushed quartz chips were used to ensure that complete thermal dissociation of the particulate species to form elemental mercury occurred. Non-mercury species such as ozone and sulfur dioxide present in the matrix may absorb or scatter light at the analytical wavelength, interfering with mercury detection in the sample. To test whether this was a possibility, ozone and sulfur dioxide were passed into the Tekran 2537A analyzer at high concentrations and no interference was found (Tekran Inc., personal communication). It may be possible that interfering species, that may be volatilized at lower temperatures during the pyrolysis, may sorb to or be deposited onto the gold trap in the analytical system and prevent complete amalgamation of mercury. An urban airshed with a high den- 


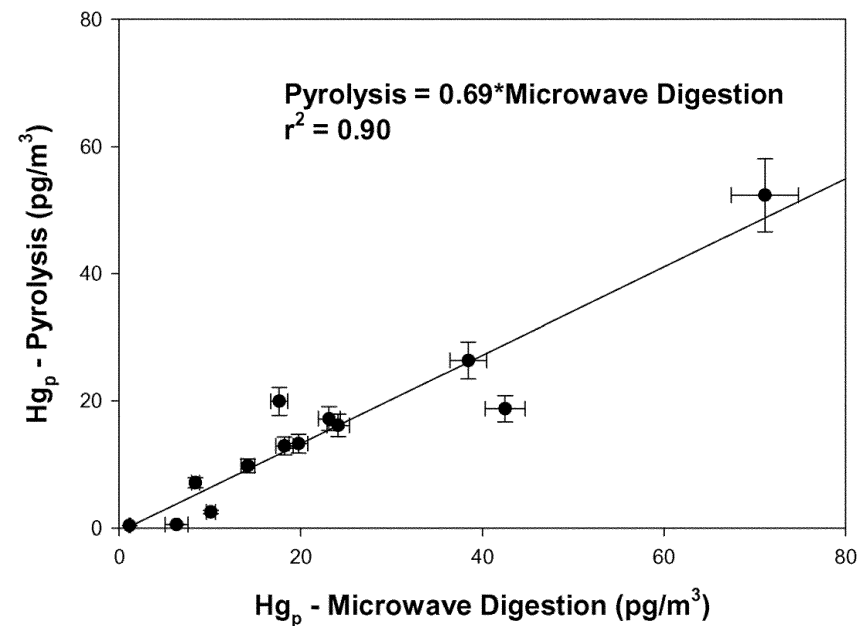

Fig. 2 Fine particulate mercury $\left(\mathrm{pg} \mathrm{m}^{-3}\right)$ in Detroit, September 2000. Error bars represent replicate analysis precision; line is a best fit of the data

sity of anthropogenic sources is likely to contain elevated levels of acidic species which can passivate a gold trap (Landis MS, personal communication).

Future methods work will focus on the removal of these matrix interferents. One approach that has been effective involves placing a soda lime trap between the exit of the pyrolysis unit and the entrance to the detector [16]. The soda lime trap will neutralize the acidic matrix interferents and facilitate the full detection of mercury present in the sample.

Artifact determination

during particulate-phase mercury sampling

\section{Source-impacted receptor site}

The USEPA's study of speciated mercury emissions from a large anthropogenic point source revealed a significant artifact due to $\mathrm{Hg}^{2+}{ }_{\mathrm{g}}$ associated with the measurement of $\mathrm{Hg}_{\mathrm{p}}$ [16]. This result indicated to us the importance of investigating this artifact in urban/source areas where levels of $\mathrm{Hg}_{\mathrm{p}}$ and vapor phase mercury are typically elevated to similar concentrations observed at the source-impacted site. Since the $\mathrm{KCl}$ denuders in front of the quartz filters were changed every $2 \mathrm{~h}$, we are confident that the elevated $\mathrm{Hg}^{2+}{ }_{\mathrm{g}}$ was completely captured and breakthrough on the denuders was not significant.

\section{Urban receptor site}

Since the highest levels of $\mathrm{Hg}_{\mathrm{p}}$ have typically been observed in urban areas $[3,4,5,6]$ the potential for $\mathrm{Hg}^{2+}{ }_{\mathrm{g}}$ species to interact with collected particulate species on quartz filters was investigated in urban Detroit. Experiments were carried out to assess how $\mathrm{Hg}^{2+}{ }_{\mathrm{g}}$ may contribute to artifact formation during $\mathrm{Hg}_{\mathrm{p}}$ measurements.

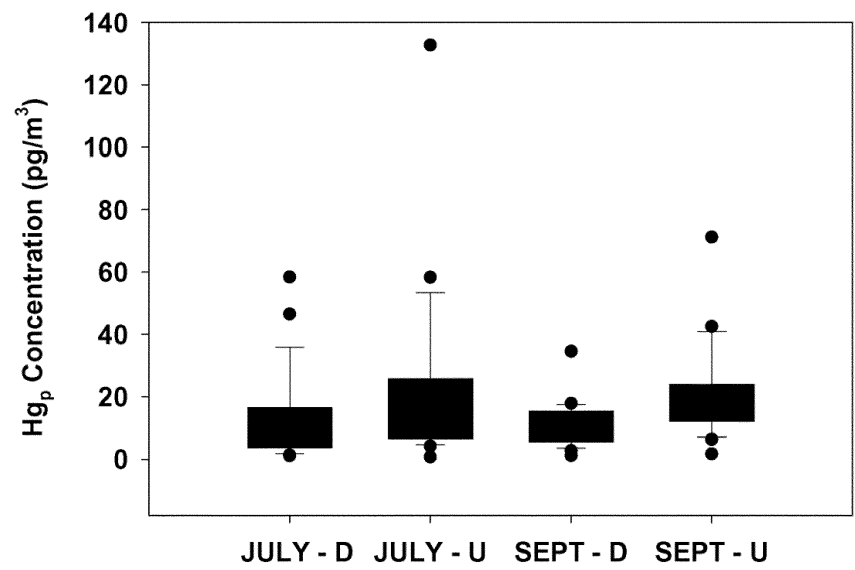

Fig.3 Summary of fine particulate mercury $\left(\mathrm{pg} \mathrm{m}^{-3}\right)$ in Detroit, July and September 2000. D denotes denuded samples and U denotes undenuded samples. The whiskers represent the 5th and 95th percentiles

Figure 3 shows a boxplot of the $\mathrm{Hg}_{\mathrm{p}}$ results from both July and September sampling campaigns. These experiments indicate a reduction in the amount of particulate phase mercury collected on filters downstream of the $\mathrm{KCl}$-coated annular denuders when compared with undenuded samples. The observed differences between the concurrent denuded and undenuded samples were found to be significant for both July (Wilcoxon test: $\mathrm{p}<0.0455, \alpha=0.05$ ) and September (Wilcoxon test: $\mathrm{p}<0.0055 \alpha=0.05$ ).

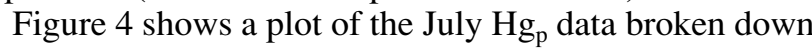
by sample duration. The $\mathrm{r}^{2}$ is 0.88 for the relationship between the two sets of data $\left(\mathrm{Hg}_{\mathrm{p} \text { undenuded }}=0.97 \times \mathrm{Hg}_{\mathrm{p} \text { denuded }}+5.6\right)$. The value of the intercept is significant and suggests that $\mathrm{Hg}^{2+}{ }_{\mathrm{g}}$ is somehow being collected on the filter. The differences between denuded and undenuded filters was found to be significant for the daytime samples (Wilcoxon test:

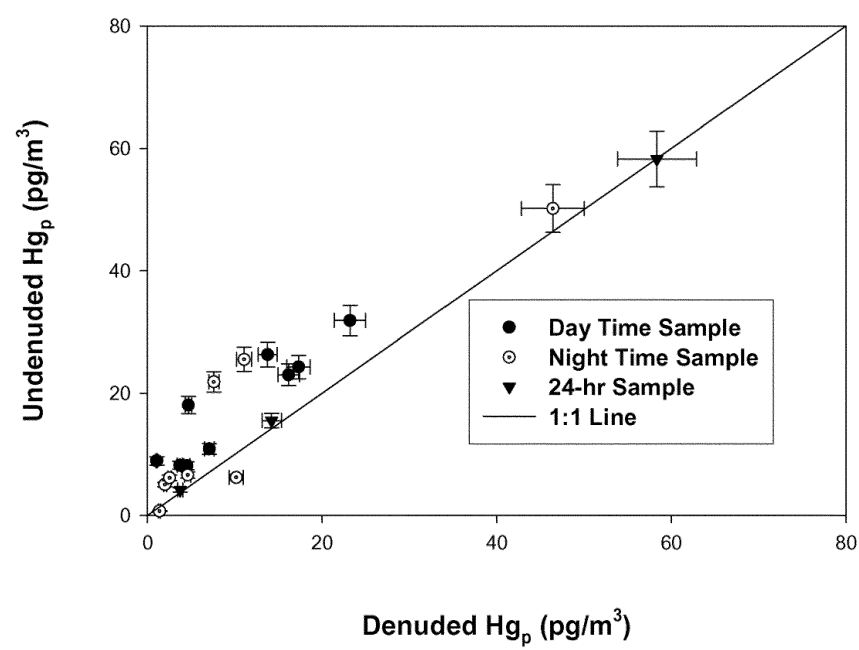

Fig. 4 Comparison of the concentration of $\mathrm{Hg}$ with/without Denuders upstream in Detroit, July 2000. Error bars represent replicate analysis precision 


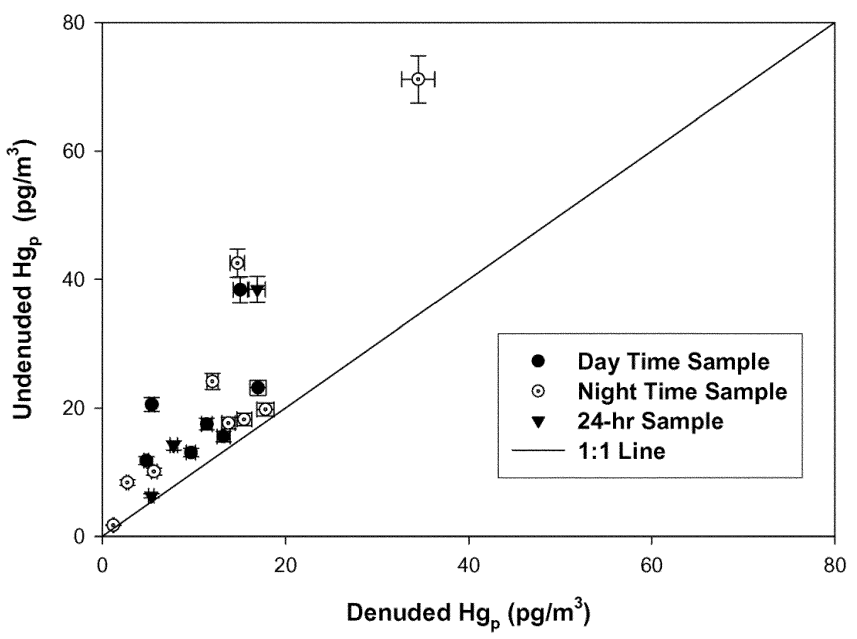

Fig. 5 Comparison of the concentration of $\mathrm{Hg}$ with/without Denuders upstream in Detroit, September 2000. Error bars represent replicate analysis precision

$\mathrm{p}<0.0260, \alpha=0.05)$ while this difference was not significant for the nighttime samples (Wilcoxon test: $\mathrm{p}<0.2818$, $\alpha=0.05$ ) A plot of the September data, Fig. 5, shows an even greater difference between denuded and undenuded filters $\left(\mathrm{Hg}_{\mathrm{p} \text { undenuded }}=1.87 \times \mathrm{Hg}_{\mathrm{p} \text { denuded }}-0.4, \mathrm{r}^{2}=0.76\right)$. Again the difference between the denuded and undenuded filters was found to be significant for the daytime samples (Wilcoxon test: $p<0.0149, \alpha=0.05$ ) and not significant in the case of the nighttime samples (Wilcoxon test: $\mathrm{p}<0.0927$, $\alpha=0.05$ ).

As was observed by Landis et al. [16] attempts to explain the differences in the $\mathrm{Hg}_{\mathrm{p}}$ using the reactive gaseous mercury data failed to give a mass balance between the observed artifact and the ambient levels of $\mathrm{Hg}^{2+}{ }_{\mathrm{g}}$. A mass balance approach may be applied to the data, assuming that the difference between the denuded and undenuded

Table 2 Comparison of the difference between denuded and undenuded particulate mercury filters and average $\mathrm{Hg}^{2+}$ g measurements for selected days in September 2000

\begin{tabular}{llll}
\hline Date & $\begin{array}{l}\text { Sample } \\
\text { type }\end{array}$ & $\begin{array}{l}\text { Difference } \\
\left(\mathrm{pg} \mathrm{m}^{-3}\right)\end{array}$ & $\begin{array}{l}\text { Average } \mathrm{Hg}^{2+}{ }_{\mathrm{g}} \\
\left(\mathrm{pg} \mathrm{m}^{-3}\right)\end{array}$ \\
\hline $9 / 19 / 2000$ & Night & 28 & 25 \\
$9 / 20 / 2000$ & Day & 23 & 16 \\
$9 / 20 / 2000$ & Night & 0.5 & 1 \\
$9 / 21 / 2000$ & Night & 2 & 5 \\
$9 / 22 / 2000$ & Day & 3 & 3 \\
$9 / 22 / 2000$ & Night & 12 & 2 \\
$9 / 25 / 2000$ & Day & 2 & 6 \\
$9 / 25 / 2000$ & Night & 4 & 10 \\
$9 / 26 / 2000$ & Day & 6 & 3 \\
$9 / 26 / 2000$ & Night & 3 & 8 \\
$9 / 28 / 2000$ & Day & 7 & 8 \\
$9 / 28 / 2000$ & Night & 4 & 9 \\
$9 / 29 / 2000$ & Day & 15 & 14 \\
$9 / 29 / 2000$ & Night & 36 & 22 \\
\hline
\end{tabular}

filters was less than or equal to the average $\mathrm{Hg}^{2+}{ }_{\mathrm{g}}$ concentration for the sampling period. For most of the sampling period these differences were equivalent, however in some instances this difference was larger than the average $\mathrm{Hg}^{2+}{ }_{\mathrm{g}}$ concentration obtained using the 1130 speciation unit for the sampling period, as shown in Table 2 .

Some of these differences may be explained by the presence of high levels of elemental mercury observed during these sampling period which could also contribute to the observed $\mathrm{Hg}_{\mathrm{p}}$ artifact. Alternatively, the Tekran 1130 instrument was programmed to sample for $1 \mathrm{~h}$ and flush and desorb for another hour giving one-hour integrated samples which were not continuous, such that only five or seven integrated measurements were obtained during a 10/14-hour sampling period. However, since the $\mathrm{Hg}^{2+}{ }_{\mathrm{g}}$ sampling was not continuous, plumes containing elevated levels of $\mathrm{Hg}^{2+} \mathrm{g}$ (max hourly levels $=159 \mathrm{pg} \mathrm{m}^{-3}$ in previous days) may have escaped detection and these elevated levels are not reflected in the average $\mathrm{Hg}^{2+}{ }_{\mathrm{g}}$ concentration for the sampling period. If the latter situation occurs, then the difference between denuded and undenuded filters would be greater than the observed average $\mathrm{Hg}^{2+}{ }_{\mathrm{g}}$ concentration and may explain some of our observations. Meteorological parameters were also examined for those instances where the observed difference between denuded and undenuded filters was larger than the average $\mathrm{Hg}^{2+}{ }_{\mathrm{g}}$ concentration and we found that meteorological conditions did not provide further insights to our observations.

\section{Conclusions}

A comparison of acid digestion (AD) and the thermal method (TM) for analysis of $\mathrm{Hg}_{\mathrm{p}}$ samples has shown that the TM gives values which are $30 \%$ lower. This is likely to be due to the effects of matrix interferents in the sample which prevent either optimal amalgamation and/or detection of all the mercury species in the sample. Future studies will focus on the use of soda lime, and other materials, to remove potential interferents during pyrolysis.

Experiments have shown that there is a significant difference $(\alpha=0.05)$ between the amount of $\mathrm{Hg}_{\mathrm{p}}$ collected onto a filter downstream of a $\mathrm{KCl}$-coated annular denuder relative to an undenuded filter. These experiments implicate $\mathrm{Hg}^{2+}{ }_{\mathrm{g}}$ as a principal contributor to an artifact in the measurement of $\mathrm{Hg}_{\mathrm{p}}$. A correction for this artifact is not possible with the limited data set presented here. An incomplete knowledge of ambient $\mathrm{Hg}^{2+}{ }_{\mathrm{g}}$ levels did not facilitate a mass balance of the atmospheric mercury forms sampled. However, a study near a point source [16], which had semi-continuous $\mathrm{Hg}^{2+}{ }_{\mathrm{g}}$ measurements also found that a mass balance could not be determined. This suggests that the artifact may be due to a complex set of factors including sample duration, time of day, season, $\mathrm{Hg}^{2+}{ }_{\mathrm{g}}$ and perhaps elemental mercury concentrations. Meteorological conditions as well as the chemical composition of the airshed may also be determinants in artifact formation.

The thermoreductive approach presented here allows maximum flexibility for both routine monitoring as well 
as intensive field campaigns, in collecting artifact free $\mathrm{Hg}_{\mathrm{p}}$ samples using denuders coupled to size-segregated sampling inlets. Based on these findings, future sampling campaigns involving $\mathrm{Hg}_{\mathrm{p}}$ measurement should at a minimum make use of a KCl-coated annular denuder upstream of the collection filter or surface to acquire artifact free measurements of this important mercury form. The magnitude of the artifact present while sampling during the winter months must be carefully explored since levels of $\mathrm{Hg}_{\mathrm{p}}$ have been found to be higher when compared with the warmer months. While levels of $\mathrm{Hg}^{2+}{ }_{\mathrm{g}}$ tend to be lower during the winter in rural areas, the levels of $\mathrm{Hg}^{2+} \mathrm{g}$ are likely to be elevated during all seasons in areas with large point sources of $\mathrm{Hg}^{2+}{ }_{\mathrm{g}}$ such as municipal and medical waste incinerators, which may lead to overestimates of Hgp.

Acknowledgements We would like to acknowledge the USEPA Region $\mathrm{V}$ for some of the funding which supported this project. We also thank Dr Matthew Landis at USEPA-NERL for the careful collection of particulate mercury filters in the source impact studies. This work was supported, in part, by a grant from the Michigan Great Lakes Protection Fund.

\section{References}

1. Grandjean P, White RF (1999) JAMA 281:896

2. US Environmental Protection Agency (1998) Mercury study report to congress, EPA-452/R-97-003, USEPA Office of Air Planning and Standards, Office of Research and Development. US Government Printing Office, Washington, DC
3. Keeler GJ, Hoyer ME, Lamborg CH (1994) In: Watras CJ, Huckabee JW (eds) Mercury pollution integration and synthesis. Lewis, pp 231-241

4. Lamborg CH, Hoyer ME, Keeler GJ, Olmez I, Huang X (1994) In: Watras CJ, Huckabee JW (eds) Mercury pollution integration and synthesis. Lewis, pp 251-259

5. Keeler GJ, Glinsorn G, Pirrone N (1995) Water Air Soil Pollut 80:159-168

6. Gildemeister AE (2001) Dissertation, University of Michigan

7. Landis MS (1998) Dissertation, University of Michigan

8. Schroeder WH, Munthe J (1998) Atmos Environ 32:809-822

9. Xiao ZF, Munthe J (1991) 56:141-151

10. Lu JY, Schroeder WH (1999) Water Air Soil Pollut 112:279295

11. Ferm M (1979) Atmos Environ 13:1385

12. Keuker MP, Schoonbeck CAM, Wensveen-Louter AV, Slanina J (1988) Atmos Environ 22:2541

13. Koutrakis P, Wolfson JM, Slater JL, Brauer M, Spengler JD, Stevens RK, Stone CL, Environ Sci Technol 22:1463-1468

14. Dvonch JT, Graney JR, Keeler GJ, Stevens RK (1999) Environ Sci Technol 33:4522-4527

15. Galbreath KC, Zygarlicke CJ (1996) Environ Sci Technol 30: 2421-2426

16. Landis MS, Stevens RK, Schaedlich F, Prestbo E (2002) Environ Sci Technol 36:3000-3009

17. Rea AW, Keeler GJ (1998) Biogeochemistry 40:115-123

18. US Environmental Protection Agency (1999) Compendium of methods for the determination of inorganic compounds in air, chap IO-5, EPA-625/R-96/010a. USEPA Office of Research and Development, Cincinnati, $\mathrm{OH}$

19. Biester H, Nehrke G (1997) Fresenius J Anal Chem 358-452

20. Seinfeld JH, Pandis SN (1998) Atmospheric chemistry and physics. Wiley, New York 